\title{
Partial Least Square Analysis for University Student Satisfaction
}

\author{
Sinta Septi Pangastuti ${ }^{1, *}$, Tri Murniati ${ }^{2}$, Alhassan Sessay ${ }^{3}$, Heri Kuswanto ${ }^{4}$ \\ ${ }^{1}$ Statistics Department, Padjadjaran University, \\ Jl. Raya Bandung - Sumedang KM. 21 Jatinangor, West Java 45363, Indonesia. Tel. 022-7796002, Fax. 022-7796002 \\ ${ }^{2}$ Inspektorat Jenderal Kemenristekdikti, Daerah Khusus Ibukota Jakarta 10270, Indonesia \\ ${ }^{3}$ Njala University Campus, Dictrict Bo, Sierra Leone, West Africa \\ ${ }^{4}$ Statistics Department, Institut Teknologi Sepuluh Nopember, East Java 60111, Indonesia \\ Email*: sinta.septi@unpad.ac.id
}

\begin{abstract}
A university needs to identify and analyse their students' satisfaction to be able to compete with others. There are five dimensions to identify students' satisfaction, such as reliability, assurance, empathy, responsiveness, and tangibles. Related to randomness of the data, primary data collected from stratified sampling tend to violate multivariate normality test. Therefore, partial least square (PLS) might be one alternative solution since it ignores multivariate normal and multicollinearity assumptions. As a result, tangible, assurance and empathy affect student satisfaction and student satisfaction significantly affect student achievement. Therefore, we recommend to university to improve service quality especially on tangible, assurance and empathy aspect to improve student satisfaction and student achievement.
\end{abstract}

Keywords: education, partial least square, service quality

\section{INTRODUCTION}

There is an existence relationship between education and economic growth (Brunat, 2006). From a research perspective, the education sector represents a very interesting disciplines to examine. Not only because of its impact on the country's economy, but also to know about the quality of education by student's perspective. Student's academic experience can be measure by their achievements and satisfaction towards their universities. There is a relational structure between high school students and their teacher (Zeinabadi, 2013), similar to an organization relationship between employee and supervisor.

Students usually make decision based on their own valuation effort. However, their satisfaction based on their individual preference, i.e. whether their expectation of the services met. Therefore, universities needed to work on improving their services quality through five dimensions: reliability, assurance, empathy, responsiveness, and tangibles. Reliability means receiving the service as promised, this dimension is critical in the education sector (Danish et al, 2010) where it could be a provision of a quick corrective action when mistake occur in order to regain the student's trust. Alexandris et al (2002) confirmed that this dimension is the most vitas determinant in service quality. Assurance indicates the courtesy and knowledge of employees which leads students trust and confidence. Empathy for educational context is giving individualized attention to students. For them, empathy is important because they are looking for a customized care to achieve their own goals to be able to provide good services to students, educational institutions staff should be willing to serve students and provide them with the required services promptly, while at the same time trying to solve any problem which may occur immediately, this is known as responsiveness.

In this study, we collected the primary data from Universitas Pembangunan Nasional (UPN) Veteran Surabaya. Not many years ago, this university was confirmed to be transformed into a state university. Through this research, we want to know the satisfaction of the student at UPN Veteran after their university transformed. One of the statistical methods that can be used to make an analysis of student satisfaction is a structural equation model (SEM). There are two assumptions should be met when we use SEM, they are multivariate normal and multicollinearity. When these two assumptions can't satisfy, we use another analysis. Partial least square SEM (PLS-SEM) is one method that can be used to build SEM.

\section{LITERATURE REVIEW}

\section{Partial Least Square Structural Equation Modeling (PLS-SEM)}

Partial least square is a family-based regression method introduced by Herman O.A Wold for the creation and development of models and methods for the social sciences with prediction-oriented approach. PLS has assumed free distribution of research data. PLS-SEM is an alternative method of SEM that can be used to overcome relationship problems between complex variables but small sample size data (30 to 100 data), 
considering SEM has a minimum sample size of 100 (Hair et al, 2010).

PLS used to determine the complexity of the relationship of a const and another, and the relationship of a construct and its indicators. PLS is defined by two equations, inner model and outer model. Inner model determines the specification of the relationship between the construct and the indicators. The construct is divided into two, namely exogenous and endogenousconstruct. Exogenous construct are construct of causes, construct not influenced by other construct. Exogenous construct give effect to other construct, whereas the endogenous construct are the construct described by exogenous construct. Endogenous construct are the effect of exogenous construct.

\section{Partial Least Square Structural Equation Modeling (PLS-SEM) Model}

SEM-PLS includes equation in the structural model (inner model) and measurement model (outer model) formulated as follows:

1. Structural Model (Inner Model)

The structural model with SEM-PLS is designed for the recursive model, i.e. model that describes the causal relationship between exogenous latent variables with endogenous latent variables. Recursive model or also called causal chain system in SEMPLS is formulated as follows:

$\eta_{j}=\beta_{j i} \eta_{i}+\gamma_{j b} \xi_{b}+\zeta_{j}$

where:

$\beta_{j i}=$ the path coefficient that links the endogenous predictor,

$\gamma_{j b}=$ the path coefficient that links the exogenous predictor,

$i \ldots b=$ index range along $i$ and $b$,

$j \quad=$ latent endogenous latent variable with $j=1$, $2, \ldots, \mathrm{J}$,

$\zeta_{j} \quad=$ inner residual variable.

2. Measurement Model (Outer Model)

The measurement model shows the relationship between indicators with latent variables and evaluated by confirmatory factor analysis. The form of measurement equation model is written as follows:

a) Latent variable with reflective indicator

If the latent variable is an exogenous variable, the form of the equation as follows:

$$
\begin{aligned}
& x_{1}=\lambda_{x_{1}} \xi_{1}+\delta_{1}, \\
& x_{2}=\lambda_{x_{2}} \xi_{2}+\delta_{2}, \\
& \vdots \\
& x_{q}=\lambda_{x_{q}} \xi_{q}+\delta_{q},
\end{aligned}
$$

If the latent variable is an endogenous variable it can be written in equationas follows:

$$
\begin{aligned}
& y_{1}=\lambda_{y_{1}} \eta_{1}+\varepsilon_{1}, \\
& y_{2}=\lambda_{y_{2}} \eta_{2}+\varepsilon_{2}, \\
& \vdots \\
& y_{p}=\lambda_{y_{p}} \eta_{p}+\varepsilon_{p}
\end{aligned}
$$

b) Latent variable with formative indicators

If the latent variable is an exogenous variable, the equation is written as following:

$\xi_{j}=\sum_{h=1}^{J} \lambda_{j h} x_{j h}+\delta_{j}$

If the latent variable is an endogenous variable, the equation is written as following:

$$
\begin{aligned}
& \eta_{i}=\sum_{h=1}^{I} \lambda_{i h} y_{i h}+\varepsilon_{j} \\
& \text { where: } \\
& \eta=\lambda_{1} y_{1}+\lambda_{2} y_{2}+\cdots+\lambda_{p} y_{p}+\varepsilon, \\
& \text { and } \\
& \mathrm{E}(\varepsilon)=0, \operatorname{Cov}(\varepsilon)=\Theta \varepsilon \\
& \mathrm{E}(\delta)=0, \operatorname{Cov}(\delta)=\Theta \delta
\end{aligned}
$$

\section{Weight Relation}

Model specifications on the measurement model and structural model are performed in the conceptual level and not the real value of a score latent variables. Therefore, the weight of the relation (weight relation) must be defined. One of the advantages in the PLS model is the possibility to estimate the value of the latent variable score. The case value for each variable latent estimate are defined as follows:

$\xi_{b}=\sum_{k b} W_{k b} X_{k b}$

$\eta_{i}=\sum_{k i} W_{k i} X_{k i}$

where $W_{k b}$ and $W_{k i}$ are the $k$ weights used to form an estimate latent variable $\xi_{b}$ and $\eta_{i}$. Estimation of latent variable is linier aggregate of indicator weight value, obtained by the PLS model estimation procedure.

\section{Estimation Model}

The estimation on the PLS model can be done by the least square method with iterative partial least square nonlinear algorithms (NIPALS). The iteration technique performed in the PLS consists of three stages (Ghozali, 2014) as follows:

1) The first iteration produces a weight estimate andis used to generate score (score factor) on latent variables. Weight estimate is used to test validity and reliability.

2) The second iteration produces a path estimate reflects the weight (weight) contribution variation changes latent variables exogenous to endogenous latent variables. That weights yields a value R-Square which appears in endogenous latent variables. Estimated value generated including the values of beta coefficients $(\beta)$ and gamma $(\gamma)$. In addition, it is generated loading factor estimation, ie lambda $(\lambda)$, which is the coefficient of outer model.

3) The third iteration yields the mean and location estimation score parameters (location parameters / 
regression constants) for indicators and latent variables.

\section{Bootstrap Method}

In the bootstrap method, resampling with replacement or create pseudo data (data shadows) that use information from the original data while keeping in mind characteristic so that resampling data is similar to the original data. The resampling method on a PLS with a small sample using the standard bootstrap error method for assess the level of significance and gain stability estimation of the measurement modeland structural models by finding estimates of standard errors (Chin, 1998). The standard bootstrap method of error $\theta$ is calculated by the standard deviation of $\theta$ replication, as follows:

$\widehat{\operatorname{se}}\left(\widehat{\theta}^{*}\right)=\sqrt{\frac{\sum_{b=1}^{B}\left(\widehat{\theta}_{b}^{*}-\widehat{\theta}^{*}\right)^{2}}{B-1}}$

\section{PLS-SEM Evaluation Model}

In SEM-PLS there is no certain assumptions distribution, therefore, the parametric technique to test significance of parameters is not required (Hair et al, 2010). PLS evaluation model based on predictor measurements that have nonparametric properties. Ghozali (2014) mentioned that evaluation of PLS model was done with evaluate outer model and inner model.

Table 1. Evaluation Criteria of PLS Model According (Chin, 1998).

\begin{tabular}{|c|c|c|}
\hline \multicolumn{2}{|c|}{ Criteria } & Evaluation rule \\
\hline \multicolumn{3}{|c|}{ Structural Model Evaluation } \\
\hline \multicolumn{2}{|c|}{ R-Square for endogenous latent variable } & $\begin{array}{l}\text { R-Square results of } 0.67,0.33 \text {, and } 0.19 \text { indicates for "good", } \\
\text { "moderate", and "weak" model }\end{array}$ \\
\hline \multicolumn{2}{|c|}{ Estimation of path coefficient } & $\begin{array}{l}\text { Estimated value for the path relationship in the model structural should } \\
\text { be significant }\end{array}$ \\
\hline \multicolumn{2}{|l|}{ f square for effect size } & $\begin{array}{l}\text { Value F-square equal to } 0.02,0.15 \text { and } 0.35 \text { can be interpreted that the } \\
\text { predictor latent variables have small, medium and large at the structural } \\
\text { level }\end{array}$ \\
\hline \multicolumn{2}{|l|}{ Q- square } & $\begin{array}{l}\text { The value of Q-square above zero provides evidence that the model has } \\
\text { predictive relevance }\end{array}$ \\
\hline \multicolumn{3}{|c|}{ Evaluation Measurement Model with Formative Indicator } \\
\hline \multicolumn{2}{|c|}{ Significance of weight value } & $\begin{array}{l}\text { Estimated value for the formative measurement model measurement } \\
\text { model should be significant }\end{array}$ \\
\hline \multicolumn{2}{|l|}{ Multicollinearity } & VIF value above 10 , indicates there is multicollinearity \\
\hline \multicolumn{3}{|c|}{ Evaluation Measurement Model with Reflective Indicator } \\
\hline \multirow{3}{*}{$\begin{array}{l}\text { Validity convergent } \\
\text { Loading factor }\end{array}$} & Loading factor & $>0.70$ (for confirmatory / ideal research) \\
\hline & & $>0.50$ (for explanatory research and confirmatory) \\
\hline & $\begin{array}{l}\text { Average variance extracted } \\
\text { (AVE) }\end{array}$ & AVE value must be above 0.50 \\
\hline \multirow[t]{2}{*}{ Validity discriminant } & $\begin{array}{l}\text { AVE square root and } \\
\text { intercorrelation latent } \\
\text { variables }\end{array}$ & $\begin{array}{l}\text { The square root value of AVE should be more } \\
\text { bigger than correlation values between variables } \\
\text { latent }\end{array}$ \\
\hline & Cross loading & $\begin{array}{l}\text { It is expected that each block of indicators has a higher loading for any } \\
\text { latent variables measured, compared with the indicator for other latent } \\
\text { variables }\end{array}$ \\
\hline Reliability & Composite reliability & $\begin{array}{l}\text { Composite reliability measures internally consistency and its value } \\
\text { must be above } 0.60 \\
\text { (for exploratory research and } \\
\text { confirmatory) and above } 0.70 \text { (for confirmatory research) }\end{array}$ \\
\hline
\end{tabular}

\section{Service Quality}

Five perspectives of service quality have been identified by Parasuraman et al in Bharwana (2013). These are empathy, reliability, responsiveness, assurance and tangibles which connect particular service character with hopes of customers.

a) Tangibles - corporal impression of human resources, conveniences and equipment

b) Empathy - more attention towards things individually and concern about them c) Assurance - employee's awareness and politeness and their potential to deliver faith and self-belief

d) Reliability - potential of institute, organization and employees to carry out service in promised and correct way

e) Responsiveness - willingness of employees to help customers when they needed and deliver quick service to them. 


\section{Hypothesis of the Research}

1) Relationship between five dimensions with customer satisfaction

Previous literature had shown that a direct effects model to investigate service quality program based on different samples. The outcomes of those studies reported that the willingness of service providers to properly implement tangibility, responsiveness, reliability, empathy, and assurance in delivering services had been the major determinants of customer satisfaction (Bitner, 1990) in Ismail (2013). The findings of those studies had strongly supported the notion of conceptual service quality model, which revealed that matching between service quality standards and customers' standards might serve to decrease service performance gap and increase customer satisfaction about the quality systems (Parasuraman, 1988). Consistent with these findings, the researchers have hypothesized the following:

H1: There is a positive relationship between tangibles and students' satisfaction

H2: Empathy is positively correlated with students' satisfaction

H3: There is a positive relationship between assurance and students' satisfaction

$\mathrm{H} 4$ : Responsiveness is positively related with satisfaction of students

H5: There is a positive and significant relationship between reliability and students' satisfaction

2) Relationship between student's satisfaction and student's achievement

Low levels of satisfaction among teachers and/or students can negatively impact student's achievement. Research shows that higher levels of worker satisfaction are correlated with higher levels of employee success and/or productivity, and lower levels of satisfaction are correlated with lower levels of productivity and/or success (Netmeyer et al, 2013). Satisfaction is an important aspect of student success, and higher satisfaction levels have been reported to coincide with higher levels of academic achievement (Brown et al, 2004). The researchers have hypothesized the following:

H6: There is a positive and significant relationship between students' satisfaction and student achievement

\section{MATERIALS AND METHODS}

\section{Data Collection}

In this paper, the dataset was collected via face-to-face interview conducted by 100 college students who study at UPN Veteran Surabaya. The sampling methods that we used are present in the table below:
Table 2. Description of Total Population per Faculty at UPN Surabaya.

\begin{tabular}{ll}
\hline Faculty & Total \\
\hline Faculty of Engineering & 4037 \\
Faculty of Law & 548 \\
Faculty of Economy and Business & 2606 \\
Faculty of Social and Politics Science & 2008 \\
Faculty of Agriculture & 848 \\
Population Total & 10047 \\
\hline
\end{tabular}

To determine the number of samples, we use Slovin formula:

$$
n=\frac{N}{1+N e^{2}}=\frac{10047}{1+10047\left(0.1^{2}\right)}=99.9 \approx 100
$$

where:

$$
\begin{array}{ll}
n & : \text { total sample } \\
\mathrm{N} & : \text { total population } \\
e & : \text { sample error }
\end{array}
$$

Therefore, the number of samples taken in this study is 100 respondents and divided according to the proportion of each faculty:

Table 3. Sample Size with Proportion

\begin{tabular}{lcc}
\hline Faculty & Total & $\begin{array}{c}\text { Sample } \\
\text { Size }\end{array}$ \\
\hline Faculty of Engineering & 4037 & 40 \\
Faculty of Law & 548 & 6 \\
Faculty of Economy and Business & 2606 & 26 \\
Faculty of Social and Politics Science & 2008 & 20 \\
Faculty of Agriculture & 848 & 8 \\
Total & 10047 & 100 \\
\hline
\end{tabular}

\section{Variable Identification}

In this study we used 6 variable latent and 26 variable manifest show in table below:

Table 4. Description of Research Variable.

\begin{tabular}{cccc}
\hline $\begin{array}{c}\text { Latent } \\
\text { Variable }\end{array}$ & $\begin{array}{c}\text { Manifest } \\
\text { Variable }\end{array}$ & $\begin{array}{c}\text { Latent } \\
\text { Variable }\end{array}$ & $\begin{array}{c}\text { Manifest } \\
\text { Variable }\end{array}$ \\
\hline Tangible & $\mathrm{X}_{11}$ & & $\mathrm{X}_{41}$ \\
& $\mathrm{X}_{12}$ & & $\mathrm{X}_{42}$ \\
& $\mathrm{X}_{13}$ & Assurance & $\mathrm{X}_{43}$ \\
& $\vdots$ & & $\mathrm{X}_{44}$ \\
\hline & $\mathrm{X}_{113}$ & & \\
\hline Reliable & $\mathrm{X}_{21}$ & & $\mathrm{Y}_{11}$ \\
& $\mathrm{X}_{22}$ & Student & $\mathrm{Y}_{12}$ \\
& $\mathrm{X}_{23}$ & Satisfaction & $\mathrm{Y}_{13}$ \\
& $\mathrm{X}_{24}$ & & $\mathrm{Y}_{14}$ \\
& $\mathrm{X}_{25}$ & & $\mathrm{Y}_{15}$ \\
\hline Responsi & $\mathrm{X}_{31}$ & Student & $\mathrm{Y}_{21}$ \\
veness & $\mathrm{X}_{32}$ & Achievement & $\mathrm{Y}_{22}$ \\
\hline
\end{tabular}

\section{Data analysis}

Analysis methods follow these steps:

1) Design the Structural Equation Model (inner model)

2) Design the Measurement Model (outer model) 
3) Construct the Path Diagram (see figure 5)

4) Convert the Path Diagram into the System of Equation
a) Outer Model (see Equation 1)
b) Inner Model (see Equation 2)
c) Weight Relation (see Equation 5 and 6)

5) In this paper we are using least square estimation within the PLS include 3 things:

a) Weight estimate is used to create latent variables scores

b) Path estimate link between latent variables and loading estimation between latent variables and their indicators

c) Means and parameter locations (regression, interception constant) value for indicators and latent variables

6) Goodness of Fit

a) Outer Model

Convergent validity

The correlation between the reflexive indicator score and latent variable score. For this loading 0.5 to 0.6 is considered sufficient.

\section{Discriminant validity}

Comparing the square root average variance extracted (AVE) value of each construct with the correlation between other construct in the model, if AVE construct is greater than correlation with all other construct it is said to have good discriminant validity, the value should be greater than 0.50 .

\section{Composite reliability}

The indicator group measuring a variable has good composite reliability if it has a composite reliability of $\geq 0.77$.

b) Inner Model

Goodness of fit model: Q-Square values are between $0<\mathrm{Q} 2<1$, where getting closer to 1 means the model is getting better.

7) Hypothesis test

Hypothesis testing $(\beta, \gamma, \lambda)$ is done by Bootstrap resampling method.

Hypothesis for outer model:

$$
\begin{aligned}
& H_{0}: \lambda_{i}=0 \\
& H_{0}: \lambda_{i} \neq 0
\end{aligned}
$$

Hypothesis for inner model: the influence of exogenous latent variables on endogen

$$
\begin{aligned}
& H_{0}: \gamma_{i}=0 \\
& H_{0}: \gamma_{i} \neq 0
\end{aligned}
$$

Hypothesis for inner model: the influence of endogenous latent variables on endogen

$$
\begin{aligned}
& H_{0}: \beta_{i}=0 \\
& H_{0}: \beta_{i} \neq 0
\end{aligned}
$$

Testing hypothesis by t-test, if p-value $\leq 0.05$ hence concluded significant. Therefore, we can say that there is significant meaning of latent variables to other latent variables.

\section{RESULTS AND DISCUSSION}

\section{Partial Least Square Structural Equation Modeling}

\begin{tabular}{|c|c|c|c|c|c|}
\hline $\begin{array}{l}\text { Latent } \\
\text { Indicator }\end{array}$ & Estimate & Mean & SE & $\begin{array}{c}\text { T- } \\
\text { value }\end{array}$ & $\begin{array}{c}\text { P- } \\
\text { value }\end{array}$ \\
\hline \multicolumn{6}{|c|}{ Tangible (T) } \\
\hline $\mathrm{X}_{16}$ & 0.930 & 0.929 & 0.019 & 48.809 & 0.000 \\
\hline $\mathrm{X}_{17}$ & 0.909 & 0.908 & 0.025 & 36.575 & 0.000 \\
\hline \multicolumn{6}{|l|}{ Reliable $(R)$} \\
\hline $\mathrm{X}_{21}$ & 0.839 & 0.839 & 0.037 & 22.818 & 0.000 \\
\hline $\mathrm{X}_{22}$ & 0.879 & 0.875 & 0.031 & 28.667 & 0.000 \\
\hline $\mathrm{X}_{23}$ & 0.722 & 0.718 & 0.066 & 10.969 & 0.000 \\
\hline $\mathrm{X}_{24}$ & 0.835 & 0.833 & 0.039 & 21.543 & 0.000 \\
\hline \multicolumn{6}{|c|}{$\begin{array}{l}\text { Responsiven } \\
\text { ess }(R e)\end{array}$} \\
\hline $\mathrm{X}_{31}$ & 0.875 & 0.877 & 0.031 & 27.868 & 0.000 \\
\hline$X_{31}$ & 0.838 & 0.833 & 0.067 & 12.566 & 0.000 \\
\hline \multicolumn{6}{|l|}{$\begin{array}{l}\text { Assurance } \\
\text { (A) }\end{array}$} \\
\hline $\mathrm{X}_{41}$ & 0.875 & 0.878 & 0.022 & 39.188 & 0.000 \\
\hline $\mathrm{X}_{42}$ & 0.873 & 0.875 & 0.027 & 32.542 & 0.000 \\
\hline $\mathrm{X}_{43}$ & 0.710 & 0.707 & 0.063 & 11.197 & 0.000 \\
\hline $\mathrm{X}_{44}$ & 0.700 & 0.695 & 0.099 & 7.100 & 0.000 \\
\hline \multicolumn{6}{|c|}{ Empathy $(E)$} \\
\hline $\mathrm{X}_{51}$ & 0.885 & 0.887 & 0.035 & 25.641 & 0.000 \\
\hline$X_{52}$ & 0.686 & 0.676 & 0.112 & 6.113 & 0.000 \\
\hline \multicolumn{6}{|l|}{$\begin{array}{l}\text { Student } \\
\text { Satisfaction } \\
\text { (SS) }\end{array}$} \\
\hline $\mathrm{Y}_{11}$ & 0.923 & 0.921 & 0.016 & 56.271 & 0.000 \\
\hline$Y_{12}$ & 0.915 & 0.913 & 0.020 & 45.467 & 0.000 \\
\hline$Y_{13}$ & 0.897 & 0.895 & 0.025 & 35.843 & 0.000 \\
\hline $\mathrm{Y}_{14}$ & 0.752 & 0.746 & 0.048 & 15.715 & 0.000 \\
\hline \multicolumn{6}{|c|}{$\begin{array}{l}\text { Student } \\
\text { Achievemen } \\
t(S A)\end{array}$} \\
\hline $\mathrm{Y}_{21}$ & 0.826 & 0.826 & 0.079 & 10.485 & 0.000 \\
\hline$Y_{22}$ & 0.798 & 0.781 & 0.117 & 6.804 & 0.000 \\
\hline
\end{tabular}

Data analysis was performed using SmartPLS software, the output of parameter estimation shown in Table 5. From the table we can see that all variable has significant effect for exogenous latent variable.

Table 5. Parameter Estimation Measurement Model.

Structural model used to estimate effect of exogeneous latent variable on endogenous latent variable. For structural model service quality (tangible, reliable, responsiveness, assurance and empathy) on student satisfaction show that 3 exogeneous latent variable (Tangible, Assurance, Empathy) have significant effect. There is no effect for reliable and responsiveness variable. All of the effect has positive sign which means that service quality has positive correlation with student's satisfaction. This model gets $68.3 \%$ for R-Square, show that service quality good enough to explained student satisfaction. According to Chan (1998) for a good model, the value of R-Square of endogenous latent variable should be more than $26 \%$. It's mean that the model is considered to have substantial 
degree of explained variance of student satisfaction by service quality factors.

Second structural model show that student satisfaction has positive and significant correlation with student achievement. This model gets R-square $30.1 \%$, so the model categorized in moderate model.

Table 6. Parameter Estimation Structural Model.

\begin{tabular}{lccccc}
\hline & Estimate & Mean & SE & T-value & P-value \\
\hline $\mathbf{T} \rightarrow$ SS & 0.221 & 0.211 & 0.104 & 2.137 & 0.033 \\
$\mathbf{R} \rightarrow$ SS & -0.027 & -0.017 & 0.091 & 0.296 & 0.768 \\
$\mathbf{R e} \rightarrow$ SS & 0.145 & 0.145 & 0.105 & 1.378 & 0.169 \\
$\mathbf{A ~} \rightarrow$ SS & 0.242 & 0.249 & 0.095 & 2.535 & 0.012 \\
$\mathbf{E} \rightarrow \mathbf{S S}$ & 0.428 & 0.422 & 0.081 & 5.299 & 0.000 \\
$\mathbf{S S ~} \rightarrow$ SA & 0.548 & 0.549 & 0.081 & 6.756 & 0.000 \\
\hline
\end{tabular}

Test for multicollinearity will do with VIF. The value should not greater than 10 so the variable has not perfectly correlated with others variable.

Table 7. VIF Value for Each Variables.

\begin{tabular}{llll}
\hline Variable & VIF & Variable & VIF \\
\hline $\mathrm{X}_{16}$ & 1.918 & $\mathrm{X}_{43}$ & 1.629 \\
$\mathrm{X}_{17}$ & 1.918 & $\mathrm{X}_{44}$ & 1.614 \\
$\mathrm{X}_{21}$ & 2.011 & $\mathrm{X}_{51}$ & 1.077 \\
$\mathrm{X}_{22}$ & 2.459 & $\mathrm{X}_{52}$ & 1.077 \\
$\mathrm{X}_{23}$ & 1.405 & $\mathrm{Y}_{11}$ & 3.766 \\
$\mathrm{X}_{24}$ & 2.051 & $\mathrm{Y}_{12}$ & 3.710 \\
$\mathrm{X}_{31}$ & 1.281 & $\mathrm{Y}_{13}$ & 3.268 \\
$\mathrm{X}_{31}$ & 1.281 & $\mathrm{Y}_{14}$ & 1.604 \\
$\mathrm{X}_{41}$ & 2.688 & $\mathrm{Y}_{21}$ & 1.114 \\
$\mathrm{X}_{42}$ & 2.702 & $\mathrm{Y}_{22}$ & 1.114 \\
\hline
\end{tabular}

Goodness of fit test for model structural can be seen from Q-square value below.

$$
\begin{gathered}
Q^{2}=1-\left(1-R_{1}{ }^{2}\right)\left(1-R_{2}{ }^{2}\right) \\
Q^{2}=1-(1-0.301)(1-0.683)=0.778
\end{gathered}
$$

If Q-Square value close to 1 means structural model fit to the data.

The Cohen's Indicator (F-Square) is obtained by the inclusion and exclusion of model constructs (one by one). Just how useful each construct is for the adjustment model is evaluated. Values of $0.02,0.15$ and 0.35 are considered small, medium, and large respectively (Hair et al, 2010).

Table 8. F-Square Value.

\begin{tabular}{ccccccc}
\hline & T & R & Re & A & E & SS \\
\hline SA & & & & & & $\mathbf{0 . 4 3 0}$ \\
SS & 0.077 & $\mathbf{0 . 0 0 1}$ & 0.033 & 0.093 & $\mathbf{0 . 3 4 1}$ & \\
\hline
\end{tabular}

Variable tangible, responsiveness and assurance categorized in medium. Variable empathy and student satisfaction categorized in large useful. Measurement model evaluation is aimed to evaluate the consistency and validity of the manifest variables. Consistency evaluations are through individual manifest and construct reliability tests. While validity of the variables is tested based on convergent and discriminant validity, individual manifest reliability explains the variance of individual manifest relative to latent variable by calculating standardized outer loadings of the manifest variables. Henseler et al (2016) suggested that manifest variable with loading values between 0.4 and 0.7 should be reviewed before elimination. Loading value indicates the factor loading of each indicator. From Table 9 we know that every variable has loading more than 0.7 . It means every variable valid in describe latent variable.

\begin{tabular}{|c|c|c|c|c|}
\hline $\begin{array}{l}\text { Latent } \\
\text { Indicator }\end{array}$ & : & 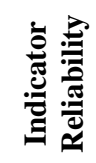 & 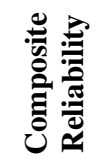 & 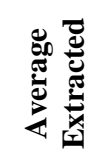 \\
\hline Tangible (T) & & & 0.916 & 0.845 \\
\hline $\mathrm{X}_{16}$ & 0.930 & 0.865 & & \\
\hline $\mathrm{X}_{17}$ & 0.909 & 0.826 & & \\
\hline Reliable $(R)$ & & & 0.891 & 0.674 \\
\hline$X_{21}$ & 0.839 & 0.704 & & \\
\hline $\mathrm{X}_{22}$ & 0.879 & 0.773 & & \\
\hline $\mathrm{X}_{23}$ & 0.722 & 0.521 & & \\
\hline $\mathrm{X}_{24}$ & 0.835 & 0.697 & & \\
\hline $\begin{array}{l}\text { Responsivene } \\
\text { ss }(\operatorname{Re})\end{array}$ & & & 0.846 & 0.734 \\
\hline $\mathrm{X}_{31}$ & 0.875 & 0.766 & & \\
\hline $\mathrm{X}_{31}$ & 0.838 & 0.702 & & \\
\hline Assurance (A) & & & 0.871 & 0.631 \\
\hline $\mathrm{X}_{41}$ & 0.875 & 0.766 & & \\
\hline $\mathrm{X}_{42}$ & 0.873 & 0.762 & & \\
\hline $\mathrm{X}_{43}$ & 0.710 & 0.504 & & \\
\hline $\mathrm{X}_{44}$ & 0.700 & 0.490 & & \\
\hline Empathy $(E)$ & & & 0.767 & 0.626 \\
\hline $\mathrm{X}_{51}$ & 0.885 & 0.783 & & \\
\hline $\mathrm{X}_{52}$ & 0.686 & 0.471 & & \\
\hline $\begin{array}{l}\text { Student } \\
\text { Satisfaction } \\
(S S)\end{array}$ & & & 0.928 & 0.764 \\
\hline$Y_{11}$ & 0.923 & 0.852 & & \\
\hline $\mathrm{Y}_{12}$ & 0.915 & 0.837 & & \\
\hline$Y_{13}$ & 0.897 & 0.805 & & \\
\hline $\mathrm{Y}_{14}$ & 0.752 & 0.566 & & \\
\hline $\begin{array}{l}\text { Student } \\
\text { Achievement } \\
\text { (SA) }\end{array}$ & & & 0.795 & 0.660 \\
\hline$Y_{21}$ & 0.826 & 0.682 & & \\
\hline$Y_{22}$ & 0.798 & 0.637 & & \\
\hline
\end{tabular}

Table 9. Results Summary for Reflective Outer Models.

It can be seen that all of the indicators have individual indicator reliability values that are much larger than the minimum acceptable level of 0.4. Traditionally we use Cronbach's alpha to measure internal consistency reliability in social science research but it tends provide a conservative measurement in PLS- 
SEM. Prior literature has suggested the use of "Composite Reliability" as a replacement. From Table 9, such values are shown to be larger than 0.6, so high levels of internal consistency reliability have been demonstrated among all seven reflective latent variables.

To check convergent validity, each latent variable's Average Variance Extracted (AVE) is evaluated. Table 9 also has the value of the AVE, as shown in the table all AVE values are greater than the acceptable threshold of 0.5 , therefore convergent validity is confirmed.
The square root of AVE in each latent variable can be used to establish discriminant validity, if this value is larger than other correlation values among the latent variables. To compute this, a table is created in which the square root of AVE is manually calculated and written in bold on the diagonal of the table. The correlations between the latent variables are copied from the "Latent Variable Correlation" section of the default report and are placed in the lower left triangle of the table (see Table 10).

Table 10. Fornell-Larcker criterion Analysis for Checking Discriminant Validity.

\begin{tabular}{|c|c|c|c|c|c|c|c|}
\hline & $\mathbf{T}$ & $\mathbf{R}$ & $\mathbf{R e}$ & $\mathbf{A}$ & $\mathbf{E}$ & SS & $\mathbf{S A}$ \\
\hline $\mathbf{T}$ & 0.919 & & & & & & \\
\hline $\mathbf{R}$ & 0.613 & 0.821 & & & & & \\
\hline $\mathbf{R e}$ & 0.567 & 0.657 & 0.857 & & & & \\
\hline $\mathbf{A}$ & 0.621 & 0.567 & 0.558 & 0.794 & & & \\
\hline $\mathbf{E}$ & 0.456 & 0.579 & 0.522 & 0.532 & 0.791 & & \\
\hline SS & 0.633 & 0.589 & 0.612 & 0.673 & 0.718 & 0.874 & \\
\hline $\mathbf{S A}$ & 0.407 & 0.383 & 0.311 & 0.366 & 0.378 & 0.548 & 0.812 \\
\hline
\end{tabular}

For example, the latent variable Tangible's square root of AVE is 0.919. This number is larger than correlation value in the column and row of tangible. Similar observation is also made for another latent variable. The result indicates that discriminant validity is well established.

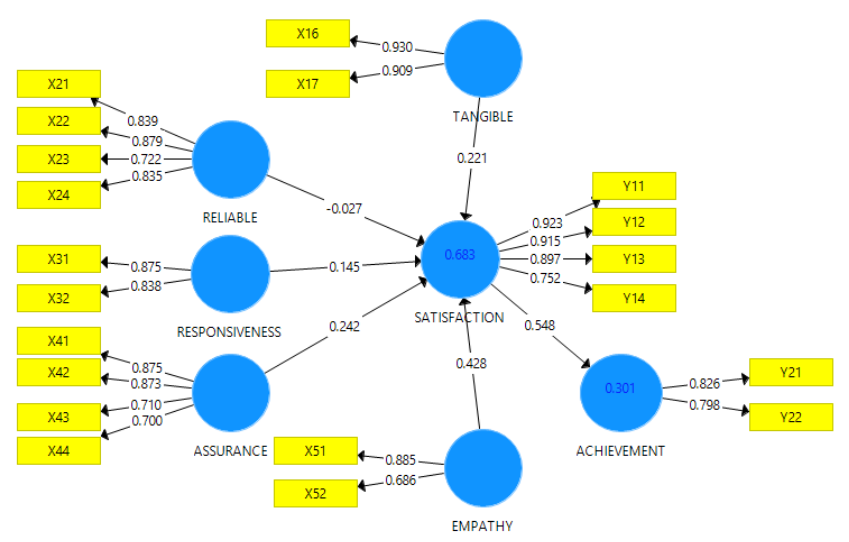

Figure 1. Visualization of PLS-SEM Model.

Based on path model there are five exogeneous latent variable that represent about survive quality. They are Tangible ( $\left.\xi_{-} 1\right)$, Reliable $\left(\xi_{-} 2\right)$, Responsiveness ( $\left.\xi_{-} 3\right)$, Assurance $\left(\xi_{-} 4\right)$, and Empathy ( $\left.\xi_{-} 5\right)$. Student satisfaction $\left(\eta_{-}\right)$is endogenous latent variable that influenced by service quality and student achievement $(\eta$ 2) is influenced by student satisfaction. Tangible influenced by two indicators informative $\left(X_{16}, X_{17}\right)$. Reliable influenced by $\mathrm{X}_{21}, \mathrm{X}_{22}, \mathrm{X}_{23}, \mathrm{X}_{24}$, responsiveness influenced by $\mathrm{X}_{31}$ and $\mathrm{X}_{32}$, assurance influenced by $\mathrm{X}_{41}$,
$\mathrm{X}_{42}, \mathrm{X}_{43}$, and $\mathrm{X}_{44}$. Empathy influenced by $\mathrm{X}_{51}$ and $\mathrm{X}_{52}$. Student achievement will be influenced by student satisfaction. The mathematical equations can be written as follows:

$$
\begin{aligned}
& \xi_{1}=\lambda_{16} X_{16}+\lambda_{17} X_{17}+\delta_{j} \\
& \xi_{2}=\lambda_{21} X_{21}+\lambda_{22} X_{22}+\lambda_{23} X_{23}+\lambda_{24} X_{24}+\delta_{j} \\
& \xi_{3}=\lambda_{31} X_{31}+\lambda_{32} X_{32}+\delta_{j} \\
& \xi_{4}=\lambda_{41} X_{41}+\lambda_{42} X_{42}+\lambda_{43} X_{43}+\lambda_{44} X_{44}+\delta_{j} \\
& \xi_{5}=\lambda_{51} X_{51}+\lambda_{52} X_{52}+\delta_{j} \\
& \eta_{1}=\gamma_{11} \xi_{1}+\gamma_{12} \xi_{2}+\gamma_{13} \xi_{3}+\gamma_{14} \xi_{4}+\gamma_{15} \xi_{5}+\lambda_{11} Y_{11} \\
& \quad+\lambda_{12} Y_{12}+\lambda_{13} Y_{13}+\lambda_{14} Y_{14}+\zeta_{j} \\
& \eta_{2}=\beta_{1} \eta_{1}+\lambda_{21} Y_{21}+\lambda_{22} Y_{22}+\zeta_{j}
\end{aligned}
$$

Table 11. Goodness of Fit.

\begin{tabular}{lcc}
\hline & Saturated Model & Estimated Model \\
\hline SRMR & 0.088 & 0.089 \\
NFI & 0.667 & 0.666 \\
\hline
\end{tabular}

For the approximate fit indices such as SRMR and $\mathrm{NFI}$, the criteria values for $0.1>\mathrm{SRMR} \geq 0.08$ and NFI $>0.90$. This model has SRMR less than 0.1 but greater than 0.08 and for NFI index less than 0.90 . Therefore, if we use SRMR for model fit, this model is good enough.

$$
G o f=\sqrt{\overline{A V E} \times \overline{R^{2}}}=\sqrt{0.705 \times 0.492}=0.59
$$

Based on the results of processing, obtained a goodness of fit value of 0.590 , it can be concluded that the model produced fit and have good ability to explain data. 


\section{CONCLUSION}

As we can see in introduction, the purpose of this analysis is to find out whether there is an influence between student satisfaction on the performance in the class. Primary data that collected from survey are sometimes violence the multivariate normality assumption, because of the randomness of the data. Therefore, structural modeling that violence the multivariate normality assumption can use Partial Least Square (PLS) approach. The result is that service quality i.e. tangible, assurance and empathy affect student satisfaction and student satisfaction significantly affect student achievement. Based on analysis we recommend to university to improve service quality especially on tangible, assurance and empathy aspect to improve student satisfaction and student achievement.

\section{REFERENCES}

Alexandris, K., James, J. 2002. Measurement of internal service quality: Application of SERVQUAL battery to internal service quality, managing service quality, 12(5): 278-291.

Asubonteng, P., McCleary, K. J., Swan, J. E. 1996. SERVQUAL revisited: a critical review of service quality. Journal of Services Marketing. 10 (6): 62-81.

Brown, K. M., Anfara, V. R., Roney, K. 2004. Student achievement in high performing, suburban middle schools and low performing, urban middle schools: Plausible explanations for the differences. Urban Society, 36(4): 428-456.

Brunat, E. 2006. The importance of higher education to attract investment and contribute to sustain economic growth and competitiveness in Kaliningrad. Baltic Rim Economic, Bimonthly Review.

Chan, T. C. 1996. Environmental impact on student learning. Valdosta, GA: Valdosta State College, School of Education. (ERIC Document Reproduction Service No. ED 406 722).

Chin, W. W. 1998. The partial least squares approach for structural equation modeling. Modern method for business research. London: Lawrence Erlbaum Associates.

Danish, R., Malik, M., Usman, A. 2010. The impact of service quality on students' satisfaction in higher education Institutes of Punjab. Journal of Management Research, 2(2).

Ghozali, I. 2014. Structural equation modeling metode alternatif dengan partial least squares (PLS). Semarang: Universitas Diponegoro.

Hair et al. 2010. Multivariate Data Analysis, Seventh Edition. Pearson Prentice Hall

Henseler, G. H., Pauline, A. R. 2016. Using PLS path modeling in new technology research: updated guidelines. Industrial Management \& Data Systems, 116(1): 2-20

Ismail et al. 2013. Examining the relationship between service quality and customer satisfaction in military peacekeeping missions. Journal of Industrial Engineering and Management, 6(2).

Netemeyer, R.G., Maxham, Lichtenstein. 2013. Store manager performance and satisfaction: effect on store employee performance and satisfaction, store customer satisfaction, and store customer spending growth. US National Library of Medicine National Institutes of Health 2010 May, 95(3): 530450.

Zeinabadi, H. R. 2013. Principal-teacher high-quality exchange indicators and student achievement: testing a model. Journal of Educational Administration, 52(3): 404-420. 